most accurate. The latest determination of the mass of a cubic inch of water is that of Mr. H. J. Chaney, superintendent of weights and measures in London, which was communicated to the Royal Society on Feb. 4, 1890. Mr. Chaney ascertained the weight of water displaced by three bodies, which he designated respectively by the letters $\mathrm{C}, \mathrm{Q}$, and $\mathrm{S}$ They were:-

(', a platinized hollow bronze circular cylinder, 9 inches in diameter and height.

Q, a quartz cylinder, 3 inches in diameter and height.

$\mathrm{S}$, a hollow 6 inch brass sphere.

With these he found as follows :-

In normal air a cubic inch of distilled water. freed from air, at the temperature of $63^{\circ} \mathrm{F}$., was found to weigh -

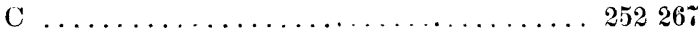

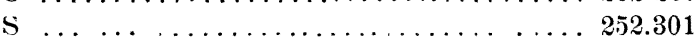

$$
\begin{aligned}
& \mathrm{Q} \ldots \ldots \ldots \ldots \ldots \ldots \ldots \ldots \ldots \ldots \ldots \ldots 252.261
\end{aligned}
$$

By normal air is meant " $\mathrm{Air}$ at $t=62^{\circ} \mathrm{F} ; p=\ddot{z} 0$ inches, containing four volumes of carbonic-anhydride in every $10000 \mathrm{vol}$ umes of air, and also containing two-thirds of the amount of aqueous vapor contained in saturated air, weighed at Westminster, latitude $51^{\circ} 29^{\prime} 53^{\prime \prime}$ - at 16 feet abore sea-level. A cubic.inch of such air weighs 0.3077 of a grain "

The International Bureau of Weights and Measures is engaged in the investigation of this constant, and when its conclusions are published the question will probably be definitely disposed of for a long time to come.

The Troughton 8:-inch scale was formerly accepted as a standard of length, but for many years it has not been actually so regarded. By reason of its faulty construction it is entirely unsuitable for a standard, and for a long time it has been of historic interest only. Since its rejection as a standard the United States yard has been considered as identical with the imperial yard of Great Britain, the material representations of which are two accurate copies, made and presented to the United States at the time of the adoption of the imperial yard.

The standard of mass has been the aroirdupois pound, identical with the imperial pound of Great Britain, except for purposes of coinage, for which the standard is the Mint Troy pound, brought from London in 1827, and which was legalized for this purpose by Act of May 19, 1828, and re-enacted in the year 1873 .

As, with a single notable exception to be referred to later, this is the only legislation by Congress upon the subject of standards, it is important to inquire by what authority the standards abore mentioned exist as such. Professor Mason has indirectly answered this. Congress having failed to take advantage of its constitutional privilege of esiablishing a uniform system of weights and measures, il became necessary to provide standards for the executive departments, by means of which taxes and revenues could be determined and collected. As the Treasury Department was mostly concerned in these matters, the questir $n$ of standards was left to it. To the first superintendent of the Coast Survey, Mr. Ferdinand Hassler, was committed the task of constructing standards having the necessary degree of precision, and he was made superintendent of the Office of Weights and Measures. The Troughton scale was brought to this country by him early in this century. A part of it was selected as the standard yard. In the absence of legislation, it will be seen that the standards of the United States Government were tho-e approved as such by the secretary of the Treasury, on the recommendation of the superintendent of Weights and Measures. In the mean time, it was known that there was great lack of uniformity among the various States. To encourage such uniformity Congress, in 1836, authorized the construction of copies of the various standards used in the Treasury Department, to be distributed to the governors of the several States. This action was taken by the Office of Weights and Measures, and did much to bring about uniformitr. At once many, and finally nearly all. of the States made these copies their standards, and thus practical uniformity was secured. Theoretically or rigorously, however. there are about as many systems of weights and measures in use to-day as there are States in the Union. There are cases, indeed, in which no legislation whatever has taken place, and, while there are severe penalties for the use of false measures, there is nothing to fix what measures are true, except, of course, as custom or common law controls.

The additional national legislation referred to above is the Act of 1866 , by which the metric system was legalized over the whole country. This is interesting and important as being the cne single bit of general statute upon the subject of weights and measures.

In 1875 the International Metric Bureau was organized. To it practically all civilized nations are now contributors. Its object was to construct and distribute prototype standards of the metre and kilogramme to the various contributing nations. These stindards were completed and distributed about three years ago. The seals upon the standards for the United States, metre No. 27 and kilogramme No. 20, were broken by Benjamin Harrison, president of the United States, on Jan. 2, 1890, in the presence of James G Blaine, the Secretarv of State, William Windom, the Secretary of the Treasury, and a number of gentlemen distinguished in the various professions in which precision in measurenent is highly regarded.

They have thus heen accepted as standards of the first authority in this country, second only to the International prototype metre and kilogramme of the International Bureau at Paris.

The metric system having thus received the recognition of the only general legislation by Congress and of executive approval, it has been determined that both the necessities of practical operations in weighing and measuring and the demands of precise metrology will b- best met by referring the units of the customary system to those of the infinitely more perfect and rapidly becoming universal system based on the metre and the kilogramme. The relations of the respective units are now so accuratels known that this may be done with an approximation entirely satisfactory.

Fortunately the law of 1866 , in its table of equivalents. $i=$ based on these relations as then known, and later investigations have only tended to confirm the value of the yard in metres as there defined. Thus the wisest course is also the easiest, and the sard and pound, as known in the Office of Weights and Measures, are now defined as a certain part of a metre and a kilogramme. respectively.

These definitions are as follows:-

1 yard $=\frac{3600}{3937}$ metre.

1 poun $1=0.453597$ kilogramme, according to the statute of 1866 .

Or more accurately -

1 English pound $=453592427 \% \mathrm{kilo}$ ramme.

These two values differ by appr sximately one part in one hundred thousand. T. C. Mendenhali

Office of Welghts and Measures, Washington, D.C.

\section{Easy Method of Calculating Complex Surveys.}

A METHOD of calculation employed by Mr. L. M Graban. manager of the McLean Co. Coal Co., of this place is new to me. and may be useful, or at least interesting, to some of your readers. In the payment of royalties on coal mined, many exceedingly complicated under ground surveys must be made.the computation of which are very difficult. Having made on a pieve of tracing paper a plat of the survey, in all its windings, he transfers this plat to a piece of cardboard; and then cuts away the cardboard, making an opening the exact form of the plat. The cardboard containing this opening is then attached to a smooth surface as a back. As a measure, he has made in cardboard an opening one inch wide and several inches long; and down the edge of this has marked a scale; one square inch representing one hundred square feet. Taking rery fine shot, he fills with this the opening in the cardboard representing the plat, taking pains to see that the shot lie but one deep; then pours these out into the measure; and readily makes his estimate. The manager says the plan was thought out by himself; and if a similar plan has been used elsewhere, he has not known of it. It strikes me as being ingenious, and widely applicable to complicated survess, whether below or above ground.

Bloomington, Iil,., Jan. 25.
R. O. GRAHAM. 